\title{
Estrogen receptor specificity for the effects of estrogen in ovariectomized mice
}

\author{
M K Lindberg, Z Weihua ${ }^{2}$, N Andersson, S Movérare, H Gao², \\ O Vidal, M Erlandsson ${ }^{1}$, S Windahl ${ }^{2}$, G Andersson ${ }^{3}$, \\ D B Lubahn ${ }^{4}$, H Carlsten ${ }^{1}, K$ Dahlman-Wright ${ }^{2}$, J-Å Gustafsson ${ }^{2}$ \\ and $\mathbf{C}$ Ohlsson
}

\author{
Division of Endocrinology, Department of Internal Medicine, Gröna Stråket 8, Sahlgrenska University Hospital, S-41345 Göteborg, Sweden \\ ${ }^{1}$ Division of Rheumatology, Department of Internal Medicine, Sahlgrenska University Hospital, S-41345 Göteborg, Sweden \\ ${ }^{2}$ Departments of Biosciences and Medical Nutrition, Karolinska Institute, Novum, S-14157 Huddinge Sweden \\ ${ }^{3}$ Division of Pathology, Karolinska Institute, Huddinge Hospital, S-14186 Huddinge, Sweden \\ ${ }^{4}$ Departments of Biochemistry and Child Health, University of Missouri-Columbia, Missouri, USA \\ (Requests for offprints should be addressed to C Ohlsson; Email: claes.ohlsson@medic.gu.se)
}

\begin{abstract}
Estrogen exerts a variety of important physiological effects, which have been suggested to be mediated via the two known estrogen receptors (ERs), $\alpha$ and $\beta$. Three-monthold ovariectomized mice, lacking one or both of the two estrogen receptors, were given estrogen subcutaneously $(2.3 \mu \mathrm{g} /$ mouse per day) and the effects on different estrogen-responsive parameters, including skeletal effects, were studied. We found that estrogen increased the cortical bone dimensions in both wild-type (WT) and double ER knockout (DERKO) mice. DNA microarray
\end{abstract}

analysis was performed to characterize this effect on cortical bone and it identified four genes that were regulated by estrogen in both WT and DERKO mice. The effect of estrogen on cortical bone in DERKO mice might either be due to remaining $\operatorname{ER} \alpha$ activity or represent an ER $\alpha / E R \beta$-independent effect. Other effects of estrogen, such as increased trabecular bone mineral density, thymic atrophy, fat reduction and increased uterine weight, were mainly ER $\alpha$ mediated.

Journal of Endocrinology (2002) 174, 167-178

\section{Introduction}

Estrogen is the most frequently prescribed medication in the United States. Estrogen deficiency increases the risk of a wide variety of illnesses, including cardiovascular diseases, obesity, rheumatoid arthritis, osteoporosis and neuro-degenerative diseases, while estrogen substitution reduces the risk of these ailments (Cosman \& Lindsay 1999). However, long-term estrogen replacement therapy is also associated with side-effects including increased risk of breast cancer and deep venous thrombosis (Daly et al. 1996, Collaborative Group on Hormonal Factors in Breast Cancer 1997). Agents that can maintain the benefit of estrogen but avoid the risks are therefore needed. Most of the effects of estrogen are exerted via the two known estrogen receptors (ERs), ER $\alpha$ and ER $\beta$. An increased understanding of the receptor specificity in different organs for the effects of estrogen is of importance for the development of such agents. We have, in the present study, determined ER specificity for the effects of estrogen on adult bone metabolism, the immune system, fat mass and the uterus.
Previous experimental bone studies have demonstrated that ovariectomy reduces trabecular bone mineral density (BMD) as well as the cross-sectional cortical bone area while estrogen substitution of ovariectomized (ovx) mice restores both these bone compartments (Turner 1999, Windahl et al. 1999, Daci et al. 2000). Estrogens are also known to exert multiple effects on the development and regulation of the immune system (Olsen \& Kovacs 1996). It is well established that estrogen is important for the development of the thymus and for estrogen-induced thymic atrophy during pregnancy (Clarke \& Kendall 1994). Exposure of adult mice to endogenous or exogenous estrogen induces massive reduction of thymic weight and cellularity (Screpanti et al. 1989).

It is well known that ovariectomy results in increased fat stores and body weight in female rodents (Couse \& Korach 1999). This effect can be prevented with estrogen and reproduced with anti-estrogen treatment in intact females (Couse \& Korach 1999). A fat-reducing effect of endogenous estrogen is supported by the fact that aromataseinactivated as well as ER $\alpha$-inactivated mice are obese (Heine et al. 2000, Jones et al. 2000, Ohlsson et al. 2000). 
A definitive role for ER $\alpha$ in the uterotrophic effects of estrogen has been confirmed in adult female ER $\alpha$ knockout mice, where there is loss of estrogen responsiveness (Lubahn et al. 1993), as well as in mice with disruption of the estrogen-responsive ring finger protein gene (Orimo et al. 1999). ER $\beta$ is present in both endometrium and myometrium and we have reported that $\mathrm{ER} \beta$ inactivated (BERKO) mice display an exaggerated estrogenic response in the immature uterus (Weihua et al. 2000). The aim of the present study was to determine the ER specificity for several different effects of estrogen in ovx mice.

\section{Materials and Methods}

\section{Animals}

Male double heterozygous $\left(\mathrm{ER} \alpha^{+/-} \beta^{+/-}\right)$mice were mated with female double heterozygous $\left(\operatorname{ER} \alpha^{+/-} \beta^{+/-}\right)$ mice, resulting in $\mathrm{ER} \alpha^{+/+} \beta^{+/+}=$wild-type (WT), $\mathrm{ER} \alpha^{-/-} \beta^{+/+}=\mathrm{ERKO}, \mathrm{ER} \alpha^{+/+} \beta^{-/-}=\mathrm{BERKO}$ and ER $\alpha^{-1-} \beta^{-1-}=$ DERKO offsprings (Lubahn et al. 1993, Krege et al. 1998, Vidal et al. 2000). The diet, housing and genetic background were as previously described (Vidal et al. 2000). In the estrogen-exposure experiments, all mice were ovariectomized at 2 months of age. Ovaries were removed after a flank incision and the incisions were closed with metallic clips. After recovery for 4 days, mice were injected s.c with $17 \beta$-estradiol benzoate $(2 \cdot 3 \mu \mathrm{g} /$ mouse per day; Sigma, St Louis, MO, USA) for 5 days/week for 3 weeks. Control mice received injections of vehicle oil (olive oil; Apoteksbolaget, Göteborg, Sweden). The dose of $17 \beta$-estradiol chosen resulted in a serum concentration of $514 \pm 184 \mathrm{pM}$. Normal serum levels of estradiol are between 70 and $110 \mathrm{pM}$ in diestrus while they are between 350 and 730 pM in estrus (Offner et al. 2000). Thus, our 17 $\beta$-estradiol treatment resulted in serum levels that were similar to those normally seen during estrus in female mice. The results on cortical bone parameters were also seen in an additional large experiment ( $n \geq 10$ in each group) in which ovx WT and DERKO mice were treated with placebo pellets or estradiol-containing pellets (Innovation Research, Sarasota, FL, USA) to re-establish circulating physiological levels of estradiol as previously described (Iafrati et al. 1997).

\section{Peripheral quantitative computerized tomography ( $p Q C T)$}

Computerized tomography was performed with the Stratec pQCT XCT Research M (software version 5.4B; Norland, Fort Atkinson, WI, USA) operating at a resolution of $70 \mu \mathrm{m}$ as previously described (Windahl et al. 1999, Vidal et al. 2000). Mid-diaphyseal pQCT scans of femur were performed to determine the cortical bone mineral content (BMC), cortical cross-sectional area and cortical thickness. The mid-diaphyseal region of the femur and humerus in mice contains mostly cortical bone. Metaphyseal pQCT scans of distal femur and proximal humerus were performed to measure trabecular volumetric BMD. The trabecular bone region was defined by setting an inner threshold to $45 \%$ of the total area.

\section{Dual X-ray absorptiometry (DXA)}

DXA measurement was performed with the Norland pDEXA Sabre (Norland) and the Sabre Research software (version 3.6) as previously described (Windahl et al. 1999).

\section{Western immunoblotting}

Western immunoblotting was performed as previously described (Skrtic et al. 1997), with some modifications. Protein $(50 \mu \mathrm{g})$, prepared from frozen bone or liver tissue, was subjected to $4-12 \%$ Bis-Tris (Novex, San Diego, CA, USA) gel electrophoresis. The primary antibody (ER $\alpha$, H-184; Santa Cruz Biotechnology, Santa Cruz, CA, USA) was diluted 1:200 and the horseradish peroxidaseconjugated secondary antibody was diluted 1:2500.

\section{DNA microarray analysis}

RNA from the humerus was prepared as described elsewhere (Chomczynski \& Sacchi 1987). The RNA was further purified using RNeasy Kit (Qiagen, Chatsworth, CA, USA). RNA from six different mice was prepared from each animal group (vehicle-treated WT, estrogentreated WT, vehicle-treated DERKO and estrogentreated DERKO). For microarray analysis, the six RNA samples were pooled in two groups of three each, resulting in two pools per animal group. The pooled RNA was reverse transcribed into cDNA, labeled and analysed by DNA microarray (MG-U74A Array; Affymetrix, Santa Clara, CA, USA). The array represents approximately 6000 mouse genes and approximately 3000 uncharacterized expression sequence tag (EST) clones. Preparation of labeled cRNA and hybridization was done according to the Affymetrix Gene Chip Expression Analysis manual.

\section{Bioinformatics}

Scanned output files were analysed using Affymetrix Micro Array Suite Version 4.0.1 software. To allow comparison of gene expression, the gene chips were globally scaled to an average intensity of 500. The estrogen-regulated genes were determined by calculating the fold change on average between vehicle-treated and estrogen-treated bone samples. For each genotype, comparisons were made between the two vehicle-treated and the two estrogen-treated gene chips, generating a total of four comparisons. An average fold change and 
Table 1 Primers and probes used in the real-time PCR analysis

$\begin{array}{clc}\begin{array}{c}\text { Bone sialoprotein } \\ \text { Acc. no. L20232 }\end{array} & \text { Forward primer } & (438-458) \\ \text { Acc. no. L20232 } & \text { Reverse primer } & (519-500) \\ \text { Acc. no. L20232 } & \text { Probe } & (498-476) \\ \text { MMP-9 } & & \\ \text { Acc. no. X72795 } & \text { Forward primer } & (1197-1219) \\ \text { Acc. no. X72795 } & \text { Reverse primer } & (1284-1262) \\ \text { Acc. no. X72795 } & \text { Probe } & (1252-1229) \\ \text { EST clone } & & \\ \text { Acc. no. Al850558 } & \text { Forward primer } & (320-345) \\ \text { Acc. no. Al850558 } & \text { Reverse primer } & (393-372) \\ \text { Acc. no. Al850558 } & \text { Probe } & (347-368) \\ \text { Collagen VIII } & & \\ \text { Acc. no. X66976 } & \text { Forward primer } \\ \text { Acc. no. X66977 } & \text { Reverse primer } & (250-274) \\ \text { Acc. no. X66976 } & \text { Probe } & (85-66) \\ & & (276-302)\end{array}$

\author{
5'-ACC CCA AGC ACA GAC TाT TGA-3' \\ 5'-CAC TTा TGG AGC CCT GCT TT-3' \\ 5'-TGC ATC TCC AGC CTT CTT GGG CA-3'
}

\author{
5'-ACA ATC CTT GCA ATG TGG ATG TT-3' \\ 5'-AAC TTC CAG TAC CAA CCG TCC $\Pi-3^{\prime}$ \\ 5'-CAG AGC GCC CTG GAT CTC AGC AAT-3'
}

\author{
5'-AAA TCA AGA CAT GGT TAT TGC TGA CT-3' \\ 5'-CCC AAC AGT GAA AAT GCT TGA A-3' \\ 5'-CCG TCC GGC TCA CAT GCA CAG A-3'
}

5'-AGT ACC CAT ACC TCC CCC AAT ATA T-3'
5'-AAC TGG CTA ACG GTA CTT CTT TGC-3'
5'-AAG GAA ATC CCA CCT GTG CCA AGA ATG-3'

MMP-9, matrix metalloproteinase 9.

coefficient of variation (CV) for the four comparisons were calculated. This calculated CV was dependent both on the assay variation and on the biological variation between the two pools included in each experimental group. We defined very strict criteria for genes to be regarded as regulated in DERKO mice: (1) the absolute call for the gene had to be present (Affymetrix Micro Array Suite Version 4.0.1) for all gene chips, (2) the average fold increase or decrease of the four comparisons should be at least 2.5-fold and (3) the CV for these four comparisons should be less than 30\%. Thus, we probably excluded some estrogen-regulated genes but this was done in order to avoid false positively regulated genes.

\section{Real-time PCR analysis}

The sequences for primers and probes that were used are described in Table 1. The analyses were performed using probes labeled with the reporter fluorescent dye FAM. Pre-designed primers and a probe labeled with the reporter fluorescent dye VIC, specific for $18 \mathrm{~S}$ rRNA, were included in the reactions as an internal standard. All oligonucleotide primers and probes were purchased from PE Applied Biosystems (Stockholm, Sweden). The cDNA was amplified using ABI PRISM 7700 (PE Applied Biosystems) under the following conditions: one cycle at $50{ }^{\circ} \mathrm{C}$ for $2 \mathrm{~min}$ and $95^{\circ} \mathrm{C}$ for $10 \mathrm{~min}$, followed by 50 cycles at $95{ }^{\circ} \mathrm{C}$ for $15 \mathrm{~s}$ and $60{ }^{\circ} \mathrm{C}$ for $1 \mathrm{~min}$. The mRNA amount of each gene was calculated using the 'Standard Curve Method' (multiplex reactions, following the instructions in User Bulletin No. 2, PE Applied Biosystems) and adjusted for the expression of $18 \mathrm{~S}$ rRNA.

\section{Thymus cellularity}

Thymus glands were removed and weighed. Single cell suspensions were obtained after tissue was mashed and passed through a nylon wool sieve. The cells were centrifuged at $515 \mathrm{~g}$ for $5 \mathrm{~min}$ and pelleted cells were resuspended in phosphate-buffered saline and the total number of thymocytes was calculated, using an automated cell counter (Sysmex, Kobe, Japan).

\section{Sucrose gradient analysis}

Frozen tissues (200 mg liver and $50 \mathrm{mg}$ uterus) were pulverized in a dismembrator (Braun, Melsungen, Germany) for $45 \mathrm{~s}$ at 1800 r.p.m. Pulverized tissue was added to a buffer composed of $10 \mathrm{mM}$ Tris- $\mathrm{HCl}, \mathrm{pH} 7 \cdot 5$, $1.5 \mathrm{mM}$ EDTA and $5 \mathrm{mM}$ sodium molybdate. Cytosols were obtained by centrifugation of the homogenates for $1 \mathrm{~h}$ at $4{ }^{\circ} \mathrm{C}$ at $204000 \mathrm{~g}$ in a $70 \mathrm{Ti}$ rotor. Cytosols were incubated for $3 \mathrm{~h}$ at $0{ }^{\circ} \mathrm{C}$ with $10 \mathrm{nM} \mathrm{6,7-}{ }^{3} \mathrm{H}$-labeled $\mathrm{E}_{2}$ (48 Ci/mmol; New England Nuclear, Boston, MA, USA), and the bound and unbound steroids were separated with dextran-coated charcoal. Sucrose gradient sedimentation was then carried out as described previously (Jensen et al. 1968).

Uterine histomorphology and $m R N A$ levels of interleukin (IL)- $1 \beta$ and complement C3 in uterus

Frozen sections $(5 \mu \mathrm{m})$ were stained with hematoxylin and eosin and 20 sections of each sample (four uteri in each genotype group) were evaluated under a light microscope. The mRNA levels of IL-1 $\beta$ and complement C3 in the uterus were determined as previously described (Weihua et al. 2000).

\section{Results}

\section{Effects of estrogen in DERKO mice}

The effects of estrogen in mice with both $\operatorname{ER} \alpha$ and $\operatorname{ER} \beta$ inactivated (DERKO) were compared with the effects of 


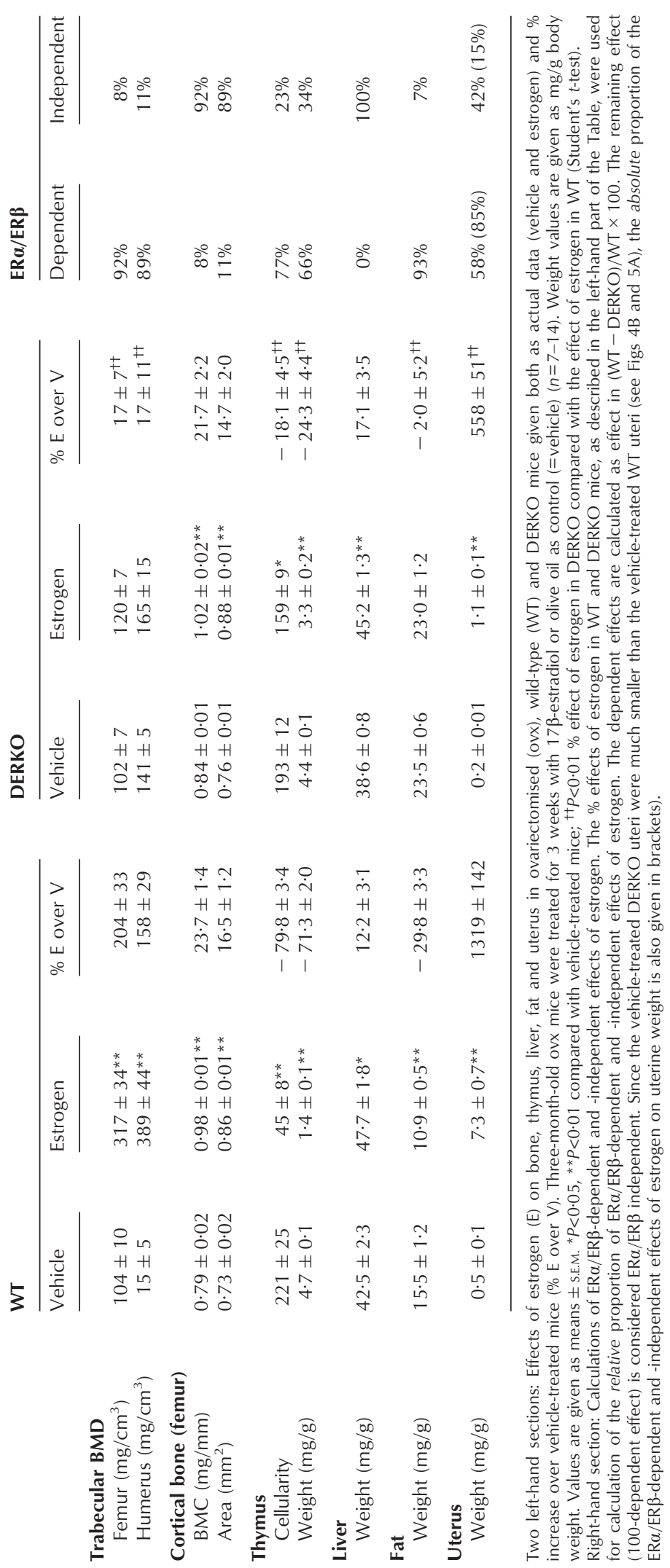



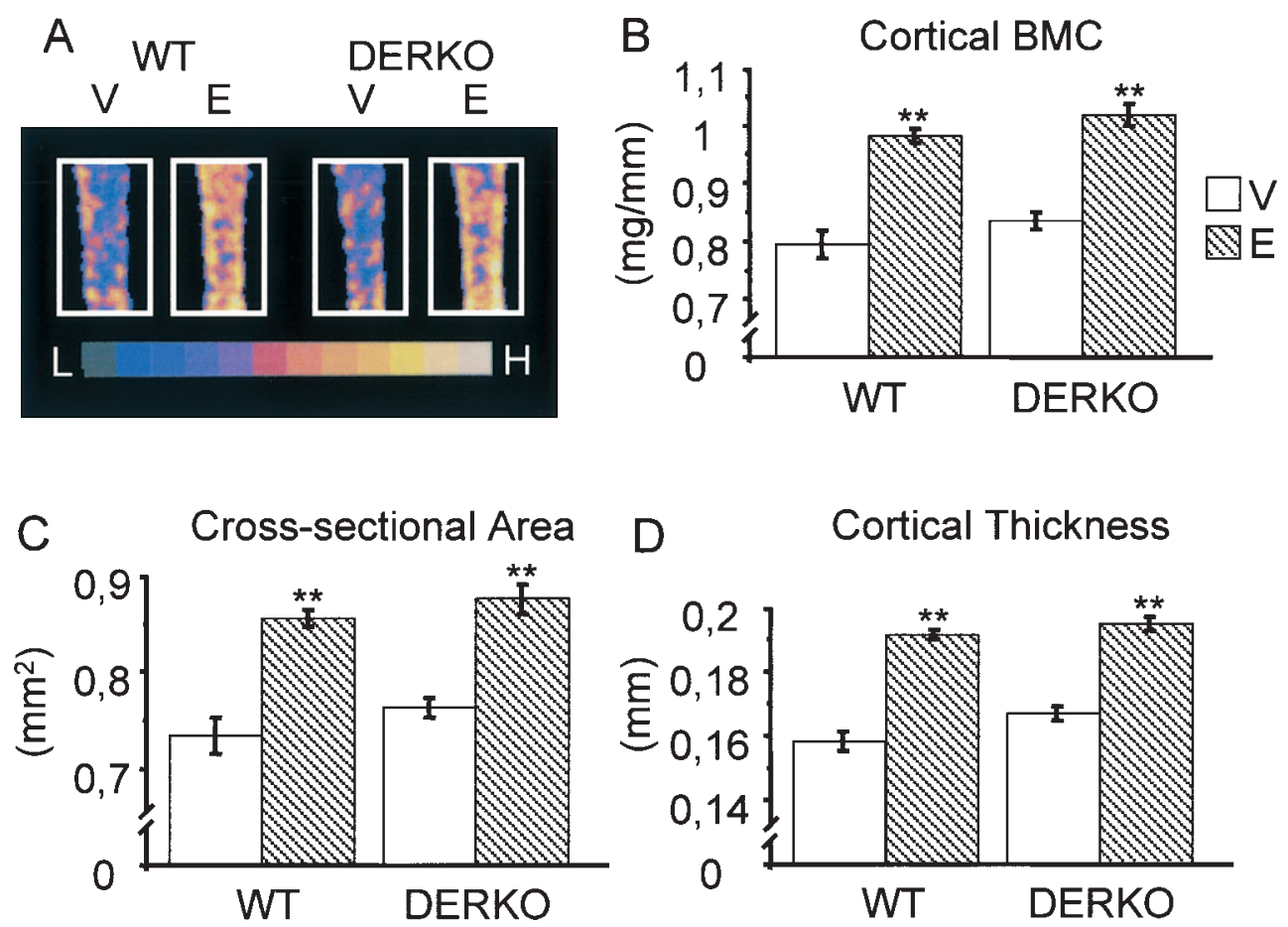

Figure 1 Effects of estrogen in DERKO mice. (A) Representative dual X-ray absorptiometry (DXA) scans of the diaphyseal region of the femur. $\mathrm{H}=$ high bone mineral density $(B M D), L=$ low $B M D, V=$ vehicle, $E=17 \beta$-estradiol. (B) Cortical bone mineral content (BMC), (C) cortical cross-sectional area and (D) cortical thickness as measured by a mid-diaphyseal peripheral quantitative computerized tomography (pQCT) scan of the femur. Three-month-old ovariectomized (ovx) mice were treated for 3 weeks with $17 \beta$-estradiol or the vehicle $(n=7-14)$. Values are given as means \pm S.E.M. ${ }^{* *} P<0.01$ compared with vehicle treatment (Student's $t$-test).

estrogen in WT mice. Estrogen treatment of ovx WT mice resulted in an increase in the trabecular BMD and cortical bone dimensions as well as in liver and uterine weight while the thymus weight and cellularity and gonadal fat mass were reduced (Table 2). Interestingly, DERKO mice exhibited an unchanged estrogenic response with regard to the increase in cortical bone dimensions and liver weight, as compared with estrogentreated WT mice (Table 2). The effect of estrogen on femoral cortical bone parameters was similar in WT and DERKO mice (Fig. 1). This cortical effect was due to an increased cortical thickness (Fig. 1D), resulting in an increased cortical cross-sectional area (Fig. 1C) and increased cortical BMC (Fig. 1A and B). DNA microarray analysis was performed to further characterize the molecular nature of the cortical bone effect in DERKO mice. Four probe sets, representing three genes and one EST clone (GenBank no. AI850558, 90\% homology with rat $\alpha 2$-macroglobulin), were found to be increased by estrogen in ovx DERKO mice (Table 3). They were also regulated in a similar manner by estrogen in ovx WT mice. To further investigate the nature of the effect of estrogen on bone and liver in DERKO mice, immunohistochemistry and sucrose gradient analysis were per- formed. Western immunoblots demonstrated ER $\alpha$ immunoreactivity in liver and bone samples from $\mathrm{ER}^{+/+}$(WT and BERKO) but not ER $\alpha^{-1-}$ (ERKO and DERKO) mice (Fig. 2A and B). Sucrose gradient analysis of cytosolic extracts from liver samples from WT mice demonstrated a peak with a sedimentation value similar to that of $E R \alpha$, while no specific estrogen binding was seen in samples from DERKO mice (Fig. 2D). Neither bone samples from WT mice nor bone samples from DERKO mice demonstrated any specific estrogen binding as determined by sucrose gradient analysis (data not shown).

\section{Estrogen exerts ERa/ER $\beta$-dependent effects}

In contrast to the effects on cortical bone and liver, the estrogenic response to several other parameters, including the trabecular BMD, thymic atrophy, gonadal fat mass and uterine weight were absent or largely reduced in DERKO mice (Table 2). Thus, these parameters were clearly ER $\alpha / \operatorname{ER} \beta$ dependent. The ER specificity was further investigated by comparing the magnitude of the effect in WT, ERKO, BERKO and DERKO mice simultaneously in the same experiment. 
Table 3 DNA microarray analysis of the effect of estrogen in ovx DERKO mice. List of mRNAs that are increased $>2 \cdot 5$-fold by estrogen in DERKO mice

Gene description

Mean fold increase

\begin{tabular}{lllll} 
& Gene description & & DERKO & WT \\
\cline { 2 - 2 } $\begin{array}{l}\text { GenBank } \\
\text { accession }\end{array}$ & & & \\
L20232 & Bone sialoprotein (BSP) & $3 \cdot 6$ & \\
X72795 & Matrix metalloproteinase 9 (MMP-9) & $2 \cdot 8$ & $1 \cdot 8$ \\
X66976 & $\alpha 1$ chain of collagen VIII & $3 \cdot 9$ & $5 \cdot 1$ \\
Al850558 & EST clone (90\% homology with rat $\alpha$-macroglobulin) & $6 \cdot 0$ & $6 \cdot 5$ \\
\cline { 5 - 5 } & & & \\
\hline
\end{tabular}

RNA from humerus from six different mice was prepared from each animal group (vehicle-treated WT, estrogen-treated WT, vehicle-treated DERKO and estrogen-treated DERKO). For microarray analysis, the six RNA samples were pooled in two groups of three each, resulting in two pools per animal group. Comparisons were made between the two vehicle-treated and the two estrogen-treated Gene Chips, generating a total of four comparisons for each genotype. An average fold change of the four comparisons was calculated. Four probe sets were identified as increased by estrogen in DERKO, using the strict criteria described in Materials and Methods. As indicated, all these four probe sets were also regulated in a similar manner by estrogen in WT mice. The effects of estrogen on mRNA levels for all four genes were confirmed by real-time PCR analysis (data not shown).
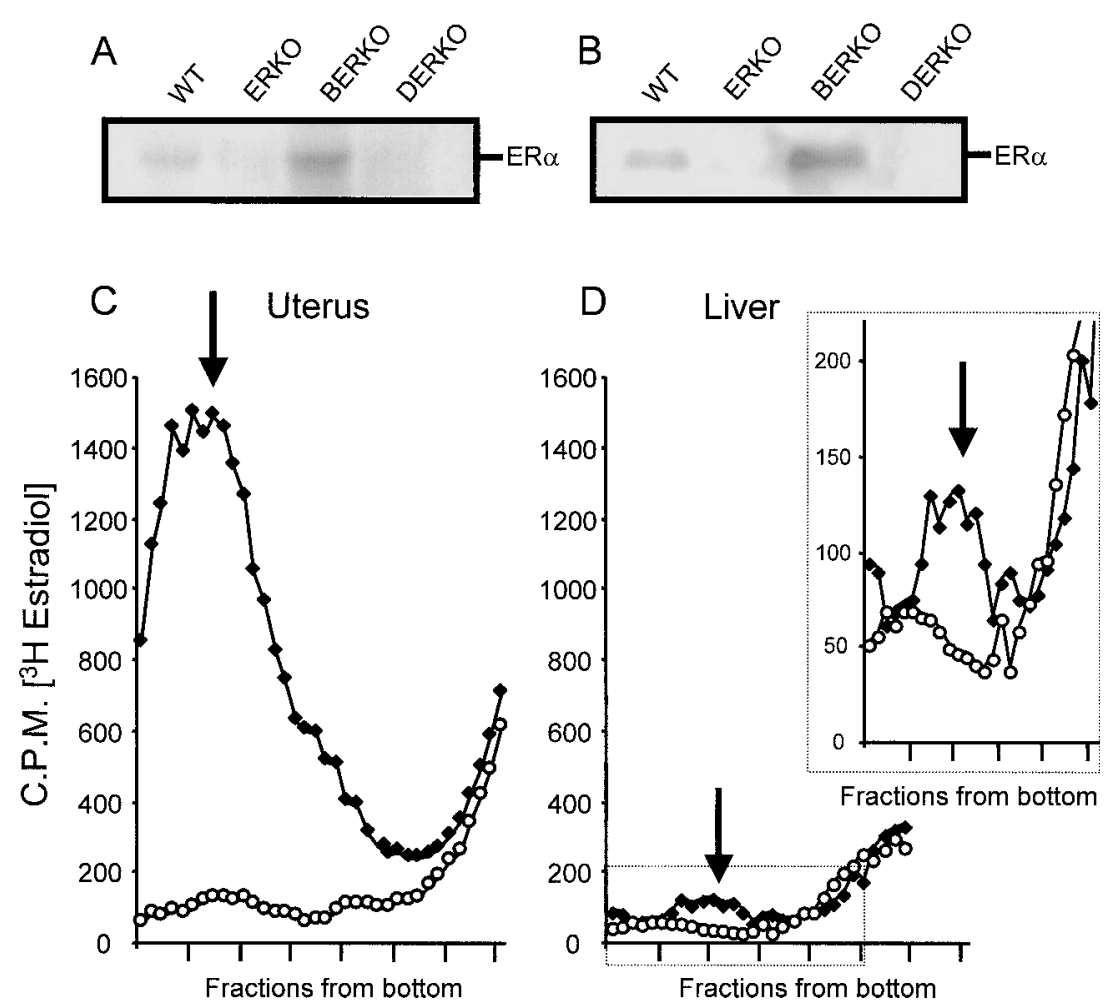

Figure 2 Estrogen receptor (ER) $\alpha$ immunoreactivity and estrogen binding. Western immunoblotting for ER $\alpha$ in (A) bone and (B) liver from WT, ERKO, BERKO and DERKO mice. Sucrose gradient analysis on (C) uterine and (D) liver extracts of WT $(\bullet)$ and DERKO $(O)$ mice. A magnification of the marked area is shown in the insert in (D). Cytosols were layered onto $10-30 \%$ sucrose gradients and centrifuged to equilibrium, and fractions were collected and counted. The arrows indicate the location of a sedimentation value similar to that of $\mathrm{ER} \alpha$ as determined by simultaneous analysis of cytosols from MCF-7 cells (data not shown). 

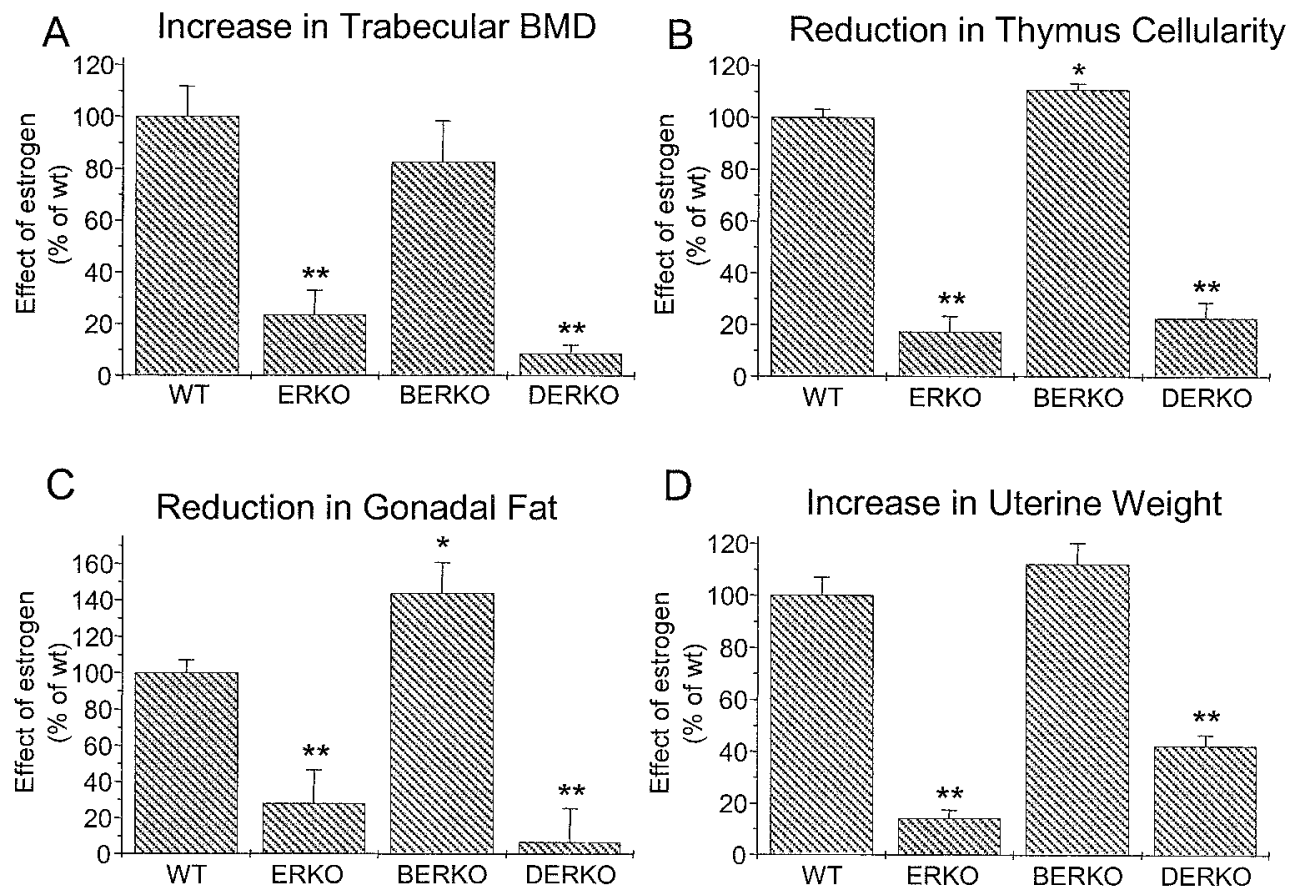

Figure 3 Estrogen exerts $E R \alpha / E R \beta$-dependent effects. (A) Increase in femur trabecular BMD, (B) reduction in thymus cellularity, $(C)$ reduction in gonadal fat and (D) increase in uterine wet weight (similar results were seen for uterine dry weight, data not shown). Three-month-old ovx mice were treated for 3 weeks with $17 \beta$-estradiol or the vehicle $(n=7-9)$. Values are given as means \pm S.E.M. and expressed as $\%$ of the effect in WT mice. ${ }^{*} P<0 \cdot 05,{ }^{* *} P<0 \cdot 01$ compared with WT mice (Student's $t$-test).

\section{Regulation of trabecular BMD is mediated via ERa}

In WT and BERKO mice, estrogen augmented trabecular BMD while no significant effect of estrogen was seen in ERKO or DERKO mice (Figs $3 \mathrm{~A}$ and $4 \mathrm{~A}$ ). Histomorphometric analysis of bone volume/total volume in the proximal metaphyseal area of tibia showed similar results as were presented for the trabecular volumetric BMD (data not shown). This finding clearly demonstrates that the effect was mainly ER $\alpha$ dependent (Figs $3 \mathrm{~A}$ and $4 \mathrm{~A})$.

\section{ER specificity for the regulation of thymic atrophy}

We have demonstrated here that ERKO and DERKO mice display a strongly reduced estrogen-induced thymic atrophy (reduction in thymus cellularity and thymus weight) while no decrease, but rather an increase, in estrogen-induced thymic involution was seen in BERKO, as compared with WT, demonstrating that $\mathrm{ER} \alpha$ is the main receptor responsible for thymic atrophy (Fig. 3B and data not shown).

\section{ER specificity for the regulation of fat mass}

In the present experiment, the gonadal fat mass was reduced by estrogen in WT and BERKO but not in
ERKO or DERKO, demonstrating that ER $\alpha$ is responsible for this effect (Fig. 3C). Similar to that seen for thymic involution, an increase in estrogenic response was found in BERKO mice (Fig. 3C).

\section{ER specificity for the regulation of uterine weight}

The estrogenic response was reduced for both the uterine wet weight and the uterine dry weight in ERKO and DERKO but not in BERKO mice, confirming the importance of ER $\alpha$ for the uterine response (Figs 3D and 4B). Histomorphology of uteri of ovx mice revealed, as expected, atrophied tissue in all of the genotypes (Fig. 4C). Upon estradiol treatment, though ERKO and DERKO uteri showed much less response than those of WT and BERKO, all four genotypes showed uterotrophic response in terms of water imbibition, elongated nucleus of luminal epithelial cells and decreased density of stromal cells (Fig. 4C). When considering the relative increase in uterine wet weight it would appear as if $42 \%$ of the effect of estrogen was preserved in DERKO mice (Table 2, Figs 3D and 4B). However, it should be emphasized that the vehicle-treated DERKO mice had much smaller uteri than the vehicle-treated WT and BERKO mice and somewhat smaller uteri than ERKO mice (WT 

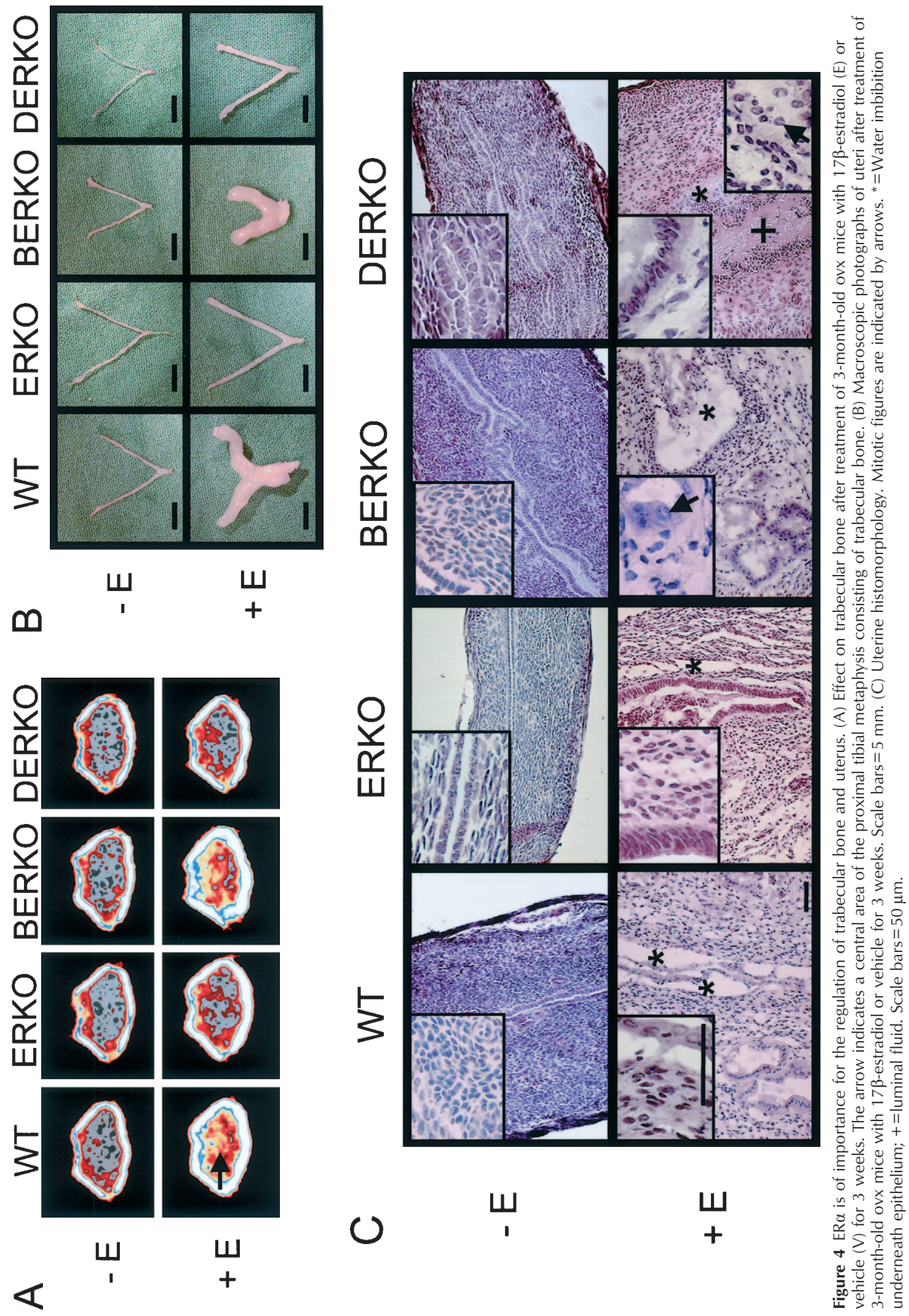

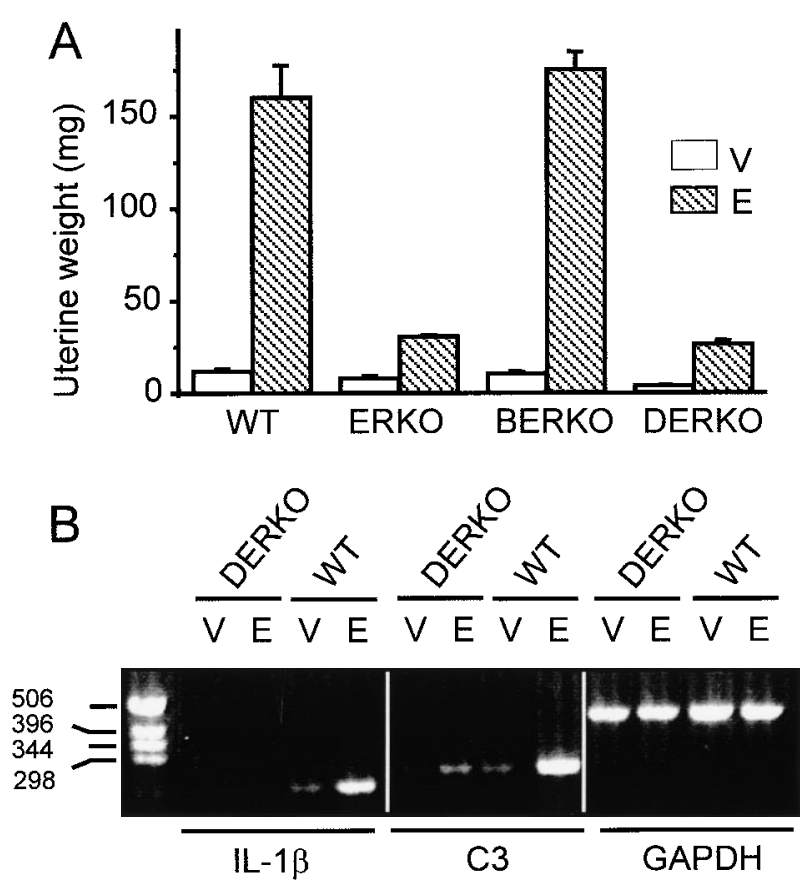

Figure 5 Effects of estrogen on uterine weight and estrogenresponsive genes in the uterus. (A) Effect on uterine wet weight after treatment of 3-month-old ovx mice with $17 \beta$-estradiol $(\mathrm{E})$ or the vehicle $(\mathrm{V})$. Values are given as means \pm S.E.M. (B) Effect of estrogen on IL-1 $\beta$ and complement C3 expression in uteri from WT and DERKO mice as studied by RT-PCR. Three-month-old ovx mice were treated for 3 weeks with $17 \beta$-estradiol or vehicle. Glyceraldehyde-3-phosphate dehydrogenase (GAPDH) was used as internal standard.

\section{$11.6 \pm 1.3 \mathrm{mg} ; \quad$ ERKO $8.0 \pm 1.3 \mathrm{mg} ; \quad$ BERKO} $10.8 \pm 0.9 \mathrm{mg}$; DERKO $3.9 \pm 0.3 \mathrm{mg}$; Figs $4 \mathrm{~B}$ and $5 \mathrm{~A}$ ). The absolute estrogen-induced increase in uterine weight was much larger in WT and BERKO mice than in ERKO and DERKO mice (Figs 4B and 5A). Thus, most of the effect of estrogen on the uterus is ER $\alpha$ dependent $(85 \%$, Table 2). Sucrose gradient analysis of uterine extracts from WT mice demonstrated a large peak with a sedimentation value similar to that of $\mathrm{ER} \alpha$ while a very small peak (approximately 4\% of the WT peak) was found with uterine extracts from DERKO mice (Fig. 2C). The effect of estrogen on IL-1 $\beta$ and complement C3 expression, two genes well known to be regulated by estrogen in the uterus, was determined in the DERKO uterus. Both IL-1 $\beta$ and C3 were induced by estrogen in WT mice, while neither of these two genes was significantly induced by estrogen in DERKO mice (Fig. 5B).

\section{Discussion}

\section{Effects of estrogen in DERKO mice}

Our results have demonstrated that DERKO mice exhibit an unchanged estrogenic response with regard to cortical bone dimensions and liver weight, indicating that estrogen exerts some effects independent of $\operatorname{ER} \alpha$ and $\operatorname{ER} \beta$. However, a recent report, which was published during the preparation of the present manuscript, suggests that the ERKO mice used in the present study are not completely ER $\alpha$ inactivated, supported by the fact that they express one or two N-terminally modified ER $\alpha$ transcripts associated with minor remaining ER activity with regard to uterine weight and endothelial nitric oxide production (Pendaries et al. 2002). The remaining ER $\alpha$ activity is suggested to be mediated via remaining activation function-2 (AF-2) activity while there is no AF-1 activity left (Pendaries et al. 2002). Thus, the ERKO and DERKO mice used in our study might have a functional $\mathrm{ER} \alpha \mathrm{AF}-2$, which may result in a minor $\mathrm{ER} \alpha$ activity. Thus, the effect of estrogen on cortical bone in DERKO mice might either be due to remaining ER $\alpha$ AF-2 activity or represent an ER $\alpha / \mathrm{ER} \beta$-independent effect.

The molecular nature of the preserved effect of estrogen on bone in DERKO mice was investigated by global gene expression analysis. DNA microarray analysis identified three genes and an EST clone, which were increased by estrogen in DERKO mice. The estrogen-induced genes in ovx DERKO mice include BSP, MMP-9 and the $\alpha 1$ chain of collagen VIII. BSP is a protein expressed by osteoblasts and associated with mineralization of bones (Ganss et al. 1999). MMP-9 has been described as being expressed by osteoblasts, osteocytes, osteoclasts and macrophages, and has been suggested to be involved in endochondral ossification (McClelland et al. 1998, Vu et al. 1998). Interestingly, it has previously been demonstrated that bone formation induced by intermittent parathyroid hormone administration is associated with a stimulation of MMP-9 expression in osteoblasts (McClelland et al. 1998). Thus, BSP and MMP-9 might be important candidate genes involved in the stimulatory effects of estrogen on cortical bone in mice. The physiological role of collagen VIII in bone is unclear but it has been reported to stimulate the production of MMP-9 (Hou et al. 2000). $\mathrm{ER} \alpha$ immunoreactivity was found in liver and bone samples from $\mathrm{ER} \alpha^{+/+}$but not $\mathrm{ER} \alpha^{-/-}$mice and it has been previously demonstrated that no ER $\beta$ immunoreactivity is detected in ER $\beta^{-/-}$mice (Krege et al. 1998). Furthermore, sucrose gradient analysis on cytosolic extracts from liver detected ER $\alpha$ in WT but not in DERKO mice. These data may indicate that the effect of estrogen on cortical bone and liver in DERKO mice might be $\operatorname{ER} \alpha / \operatorname{ER} \beta$ independent but, as described above, one cannot exclude a remaining ER $\alpha$ activity. Alternatively, estrogen has been suggested to exert non-genomic actions via cell membrane receptors in a variety of cell types, including osteoblasts (Nemere \& Farach-Carson 1998, Le Mellay et al. 1999, Kousteni et al. 2001) and the effect in DERKO mice might 
also be due to some low affinity binding to other known nuclear receptors (Kousteni et al. 2001). However, one cannot exclude the possibility that the effects on bone and liver are indirect, mediated via other mechanisms, which, for instance, might include an effect on the hypothalamic/ pituitary axis. The exact mechanism behind the effects of estrogen on cortical bone and liver in DERKO mice remains to be elucidated.

\section{Trabecular BMD effect is mediated via ERa}

Estrogen increased the trabecular BMD in ovx WT and BERKO, but not in ERKO or DERKO mice. This finding clearly demonstrates that the effect was ER $\alpha$ dependent. Interestingly, as described above, the other major bone compartment, the cortical bone, did respond to estrogen in DERKO compared with WT mice. Separate mechanisms of action for estrogen in the regulation of the trabecular bone versus the cortical bone are supported by two knockout studies demonstrating that the trabecular bone responded differently to estrogen deficiency compared with cortical bone in plasminogen activator inhibitor-1- and IL-6-deficient mice (Poli et al. 1994, Daci et al. 2000).

Thymic atrophy and fat mass effects are mediated via ERa while ER $\beta$ inhibits these effects

The present study confirmed previous studies demonstrating that ER $\alpha$ is the receptor responsible for thymic atrophy and regulation of fat mass (Staples et al. 1999, Heine et al. 2000, Ohlsson et al. 2000). Interestingly, an increased estrogenic response for these two parameters was found in BERKO mice, indicating that ER $\beta$ might act as a repressor of these $E R \alpha$-mediated effects.

\section{Uterine weight effect is mainly mediated via ERa}

The estrogenic uterine responses in mature ovx WT, ERKO, BERKO and DERKO mice have not previously been compared. Responses were reduced for both the uterine wet weight and the uterine dry weight in ERKO and DERKO but not in BERKO mice, confirming previous studies regarding the importance of ER $\alpha$ for the uterine response (Lubahn et al. 1993, Couse et al. 1999). However, there was a small but significant remaining uterotrophic effect of estrogen in ERKO and DERKO mice. A similar remaining effect of estrogen in ERKO mice has recently been reported by Pendaries et al. (2002) and shown to be dependent on the AF-2 activity of the truncated ER $\alpha$ present in the uterus of our ERKO model. Sucrose gradient analysis of uterine extracts from WT mice demonstrated a large ER $\alpha$-like peak while a very small peak was found with uterine extracts from DERKO mice. Thus, it cannot be excluded that the receptor responsible for this small remaining estrogen-binding capacity is involved in the minor uterotrophic effect of estrogen in DERKO mice. Both IL-1 $\beta$ and C3 were induced by estrogen in WT mice, while neither of these two genes was significantly induced by estrogen in DERKO mice. These measurements indicate that the effect of estrogen in DERKO uterus may, at least partly, differ from that seen in WT mice. Why, then, do vehicle-treated ovx DERKO mice have smaller uteri than vehicle-treated ovx WT mice? This might be explained by an ER $\alpha / E R \beta$-dependent stimulation by exogenous estrogens, including diet-derived phytoestrogens or by ER $\alpha / E R \beta$ being of some importance for the early development of the uterus. We have previously shown that estrogen treatment of young, sexually immature, female mice results in a more pronounced uterine response in BERKO mice compared with WT mice (Weihua et al. 2000). In contrast, the uterine response to estrogen was, in the present study, not increased in BERKO mice. However, there are two important differences between our present and our previous study: (1) in the present study the mice were sexually mature while they were immature in the previous study and (2) the mice in the present but not in the previous study were ovariectomized before treatment with estrogen.

\section{ER $\beta$ represses some ERa-mediated effects}

Although ER $\alpha$ appears to be of major importance in the $\mathrm{ER} \alpha / \mathrm{ER} \beta$-dependent responses studied in this investigation, ER $\beta$ plays an important role in some other physiological contexts. For instance, ER $\beta$ is indispensable for normal ovarian morphology and function as inferred from ER $\beta$ knockout studies in mice (Krege et al. 1998). Very recently we have also demonstrated, using the same animal model, that ER $\beta$ is necessary for normal morphology in several regions of the central nervous system (Wang et al. 2001). Studies on these animals also indicate that ER $\beta$ has an antiproliferative effect in the immature uterus and in the prostate, at least partially by balancing the proliferative activity of ER $\alpha$ ('yin-yang effect') (Weihua et al. 2000, 2001). It has also been suggested that $E R \beta$ may repress the expression of ER $\alpha$ (Windahl et al. 2001). Thus, the increased effect of estrogen on thymus involution and fat reduction in BERKO mice, observed in the current study, might be explained by an unopposed ER $\alpha$ activity.

In conclusion, estrogen increased the cortical bone dimensions in both WT and DERKO mice. DNA microarray analysis identified four genes that were regulated by estrogen in DERKO mice. The effect of estrogen on cortical bone in DERKO mice might be due either to remaining ER $\alpha$ activity or might represent an ER $\alpha / E R \beta$ independent effect. Other effects such as increased trabecular BMD, thymic atrophy, fat reduction and increased uterine weight were mainly $\operatorname{ER} \alpha$ mediated. 


\section{Acknowledgements}

This study was supported by the Swedish Medical Research Council, the Swedish Foundation for Strategic Research, the Lundberg Foundation, the Swedish Medical Society, the Novo Nordisk Foundation, the Torsten and Ragnar Söderbergs Foundation, the Emil and Vera Cornell Foundation, the Petrus and Augusta Hedlunds Foundation, the Swedish Association Against Rheumatic Disease, the Swedish Cancer Fund and Karo Bio AB. We also thank SWEGENE Center for Bio-Imaging (CBI), Göteborg University, for technical support regarding image analysis.

\section{References}

Chomczynski P \& Sacchi N 1987 Single-step method of RNA isolation by acid guanidinium thiocyanate-phenol-chloroform extraction. Analytical Biochemistry 162 156-159.

Clarke AG \& Kendall MD 1994 The thymus in pregnancy: the interplay of neural, endocrine and immune influences. Immunology Today 15 545-551.

Collaborative Group on Hormonal Factors in Breast Cancer 1997 Breast cancer and hormone replacement therapy: collaborative reanalysis of data from 51 epidemiological studies of 52705 women with breast cancer and 108411 women without breast cancer. Lancet 350 1047-1059.

Cosman F \& Lindsay R 1999 Selective estrogen receptor modulators: clinical spectrum. Endocrine Reviews 20 418-434.

Couse JF \& Korach KS 1999 Estrogen receptor null mice: what have we learned and where will they lead us? Endocrine Reviews 20 358-417.

Couse JF, Hewitt SC, Bunch DO, Sar M, Walker VR, Davis BJ \& Korach KS 1999 Postnatal sex reversal of the ovaries in mice lacking estrogen receptors alpha and beta. Science 286 2328-2331.

Daci E, Verstuyf A, Moermans K, Bouillon R \& Carmeliet G 2000 Mice lacking the plasminogen activator inhibitor 1 are protected from trabecular bone loss induced by estrogen deficiency. Journal of Bone and Mineral Research 15 1510-1516.

Daly E, Vessey MP, Hawkins MM, Carson JL, Gough P \& Marsh S 1996 Risk of venous thromboembolism in users of hormone replacement therapy. Lancet 348 977-980.

Ganss B, Kim RH \& Sodek J 1999 Bone sialoprotein. Critical Reviews in Oral Biology and Medicine 10 79-98.

Heine PA, Taylor JA, Iwamoto GA, Lubahn DB \& Cooke PS 2000 Increased adipose tissue in male and female estrogen receptor-alpha knockout mice. PNAS 97 12729-12734.

Hou G, Mulholland D, Gronska MA \& Bendeck MP 2000 Type VIII collagen stimulates smooth muscle cell migration and matrix metalloproteinase synthesis after arterial injury. American Journal of Pathology 156 467-476.

Iafrati MD, Karas RH, Aronovitz M, Kim S, Sullivan TR Jr, Lubahn DB, O’Donnell TF Jr, Korach KS \& Mendelsohn ME 1997 Estrogen inhibits the vascular injury response in estrogen receptor alpha-deficient mice. Nature Medicine 3 545-548.

Jensen EV, Suzuki T, Kawashima T, Stumpf WE, Jungblut PW \& DeSombre ER 1968 A two-step mechanism for the interaction of estradiol with rat uterus. PNAS 59 632-638.

Jones ME, Thorburn AW, Britt KL, Hewitt KN, Wreford NG, Proietto J, Oz OK, Leury BJ, Robertson KM, Yao S \& Simpson ER 2000 Aromatase-deficient (ArKO) mice have a phenotype of increased adiposity. PNAS 97 12735-12740.

Kousteni S, Bellido T, Plotkin LI, O’Brien CA, Bodenner DL, Han L, Han K, DiGregorio GB, Katzenellenbogen JA, Katzenellenbogen
BS, Roberson PK, Weinstein RS, Jilka RL \& Manolagas SC 2001 Nongenotropic, sex-nonspecific signaling through the estrogen or androgen receptors: dissociation from transcriptional activity. Cell $104719-730$.

Krege JH, Hodgin JB, Couse JF, Enmark E, Warner M, Mahler JF, Sar M, Korach KS, Gustafsson JA \& Smithies O 1998 Generation and reproductive phenotypes of mice lacking estrogen receptor beta. PNAS 95 15677-15682.

Le Mellay V, Lasmoles F \& Lieberherr M 1999 Galpha(q/11) and gbetagamma proteins and membrane signaling of calcitriol and estradiol. Journal of Cellular Biochemistry 75 138-146.

Lubahn DB, Moyer JS, Golding TS, Couse JF, Korach KS \& Smithies O 1993 Alteration of reproductive function but not prenatal sexual development after insertional disruption of the mouse estrogen receptor gene. PNAS 90 11162-11166.

McClelland P, Onyia JE, Miles RR, Tu Y, Liang J, Harvey AK, Chandrasekhar S, Hock JM \& Bidwell JP 1998 Intermittent administration of parathyroid hormone (1-34) stimulates matrix metalloproteinase-9 (MMP-9) expression in rat long bone. Journal of Cellular Biochemistry 70 391-401.

Nemere I \& Farach-Carson MC 1998 Membrane receptors for steroid hormones: a case for specific cell surface binding sites for vitamin D metabolites and estrogens. Biochemical and Biophysical Research Communications 248 443-449.

Offner H, Adlard K, Zamora A \& Vandenbark AA 2000 Estrogen potentiates treatment with $\mathrm{T}$-cell receptor protein of female mice with experimental encephalomyelitis. Journal of Clinical Investigation 105 1465-1472.

Ohlsson C, Hellberg N, Parini P, Vidal O, Bohlooly M, Rudling M, Lindberg MK, Warner M, Angelin B \& Gustafsson JA 2000 Obesity and disturbed lipoprotein profile in estrogen receptor-alphadeficient male mice. Biochemical and Biophysical Research Communications 278 640-645.

Olsen NJ \& Kovacs WJ 1996 Gonadal steroids and immunity. Endocrine Reviews 17 369-384.

Orimo A, Inoue S, Minowa O, Tominaga N, Tomioka Y, Sato M, Kuno J, Hiroi H, Shimizu Y, Suzuki M, Noda T \& Muramatsu M 1999 Underdeveloped uterus and reduced estrogen responsiveness in mice with disruption of the estrogen-responsive finger protein gene, which is a direct target of estrogen receptor alpha. PNAS $\mathbf{9 6}$ 12027-12032.

Pendaries C, Darblade B, Rochaix P, Krust A, Chambon P, Korach KS, Bayard F \& Arnal JF 2002 The AF-1 activation-function of ERalpha may be dispensable to mediate the effect of estradiol on endothelial NO production in mice. PNAS 99 2205-2210.

Poli V, Balena R, Fattori E, Markatos A, Yamamoto M, Tanaka H, Ciliberto G, Rodan GA \& Costantini F 1994 Interleukin-6 deficient mice are protected from bone loss caused by estrogen depletion. EMBO Journal 13 1189-1196.

Screpanti I, Morrone S, Meco D, Santoni A, Gulino A, Paolini R, Crisanti A, Mathieson BJ \& Frati L 1989 Steroid sensitivity of thymocyte subpopulations during intrathymic differentiation. Effects of 17 beta-estradiol and dexamethasone on subsets expressing $\mathrm{T}$ cell antigen receptor or IL-2 receptor. Journal of Immunology 142 $3378-3383$.

Skrtic S, Ekberg S, Wallenius V, Enerback S, Hedin L \& Jansson JO 1997 Changes in expression of CCAAT/enhancer binding protein alpha (C/EBP alpha) and C/EBP beta in rat liver after partial hepatectomy but not after treatment with cyproterone acetate. Journal of Hepatology 27 903-911.

Staples JE, Gasiewicz TA, Fiore NC, Lubahn DB, Korach KS \& Silverstone AE 1999 Estrogen receptor alpha is necessary in thymic development and estradiol-induced thymic alterations. Journal of Immunology 163 4168-4174.

Turner RT 1999 Mice, estrogen, and postmenopausal osteoporosis. Journal of Bone and Mineral Research 14 187-191. 
Vidal O, Lindberg MK, Hollberg K, Baylink DJ, Andersson G, Lubahn DB, Mohan S, Gustafsson JA \& Ohlsson C 2000 Estrogen receptor specificity in the regulation of skeletal growth and maturation in male mice. PNAS 97 5474-5479.

Vu TH, Shipley JM, Bergers G, Berger JE, Helms JA, Hanahan D, Shapiro SD, Senior RM \& Werb Z 1998 MMP-9/gelatinase B is a key regulator of growth plate angiogenesis and apoptosis of hypertrophic chondrocytes. Cell 93 411-422.

Wang L, Andersson S, Warner M \& Gustafsson JA 2001 Morphological abnormalities in the brains of estrogen receptor beta knockout mice. PNAS 98 2792-2796.

Weihua Z, Saji S, Makinen S, Cheng G, Jensen EV, Warner M \& Gustafsson JA 2000 Estrogen receptor (ER) beta, a modulator of ERalpha in the uterus. PNAS 97 5936-5941.

Weihua Z, Makela S, Andersson LC, Salmi S, Saji S, Webster JI, Jensen EV, Nilsson S, Warner M \& Gustafsson JA 2001 A role for estrogen receptor beta in the regulation of growth of the ventral prostate. PNAS 98 6330-6335.

Windahl SH, Vidal O, Andersson G, Gustafsson JA \& Ohlsson C 1999 Increased cortical bone mineral content but unchanged trabecular bone mineral density in female $\operatorname{ERbeta}(-/-)$ mice. Journal of Clinical Investigation 104 895-901.

Windahl SH, Hollberg K, Vidal O, Gustafsson JA, Ohlsson C \& Andersson G 2001 Female estrogen receptor beta - / - mice are partially protected against age-related trabecular bone loss. Journal of Bone and Mineral Research 16 1388-1398.

Received in final form 29 April 2002

Accepted 14 May 2002 